\title{
Developing Transparency through Digital Means? Examining Institutional Responses to Civic Technology in Latin America
}

\section{Rebecca Rumbul}

mySociety, UK, Rebecca@mySociety.org

\begin{abstract}
A number of NGOs across the world currently develop digital tools to increase citizen interaction with official information. The successful operation of such tools depends on the expertise and efficiency of the NGO, and the willingness of institutions to disclose suitable information and data. This study examines such institutional interaction with civic technology. The research explores empirical interview data gathered from government officials, public servants, campaigners and NGO's involved in the development and implementation of civic technologies in Chile, Argentina and Mexico. The findings identify the impact these technologies have had on government bureaucracy, and the existing barriers to openness created by institutionalised behaviours and norms. Institutionalised attitudes to information rights and conventions are shown to inform the approach that government bureaucracy takes in the provision of information, and institutionalised procedural behaviour is shown to be a factor in frustrating NGOs attempting to implement civic technology.
\end{abstract}

Keywords: civic technology, institutions, digital, transparency

\section{Introduction}

It is uncontroversial to state that advances in technology and connectivity have rapidly changed how both citizens and institutions have conducted business over the last 25 years. As society has developed more powerful processing abilities, it has also developed significant plurality in the way in which individuals and institutions are able to communicate. Civic technology is one of these once-niche areas of citizen-government interaction now growing in popularity. "Civic technology", described as a non-profit technology used to empower or engage citizens and make government more accountable (Knight Foundation, 2015; Patel et al, 2013), has emerged organically and in many self-contained pockets across the globe in parallel with shifts in global attitudes towards open government principles. The variety of civic technologies employed around the world is diverse, with some platforms focusing on enabling citizens to report issues in their neighbourhood to local government, and others providing user-friendly sites displaying parliamentary information. The prevailing hope of civic technology advocates is that the accessibility and interactivity of the internet will prompt governments to become more responsive 
to citizens (Anderson, 2009; Grimmelikhuijsen, 2012; Wong and Welch, 2004), and that information and communication technologies (ICTs) provide a platform to promote good governance and curb tendencies towards corruption (Bertot et al, 2010). One of the most common uses of civic technology is in the area of information rights. Multiple sites around the world have been implemented by NGOs as well as by private and public organisations to facilitate the request and provision of official information between citizen and government. The open-source Alaveteli software (Alaveteli, 2016), built by the UK-based international NGO mySociety specifically for Right To Information requests (RTI), is implemented in 21 countries worldwide, with at least 12 similar softwares also implemented. MuckRock (MuckRock, 2016), based in the USA, is another example of software designed to enable citizens to access information in the public domain. The development and implementation of such software is, however, not necessarily indicative of its success. Whilst 98 countries now have a form of RTI law, and of those 33 have a civic technology providing a platform for RTI requests, it is unclear whether the existence of such tools actually facilitates access to official information.

Civic technologies rely on the openness of governments to operate. Without access to government information, and without government responsiveness to RTI requests, the platforms will ultimately fail. Government information is the very oxygen by which civic technologies operate, and any deficiencies in the supply of such information will starve platforms of the resource required to thrive. For example, if platform-creators are unable to access the contact information for government departments, then their tools are unable to forward requests to the correct place. If requests go unanswered, users are unlikely to maintain any confidence in the ability of civic technologies to assist them. Civil society civic technologists have therefore been at the forefront of the global movement to open up government information (Calland and Bentley, 2012), and have been working globally to mobilise and campaign for change. The Open Government Partnership (OGP) was created in 2011 to promote openness in government information and to share and encourage best practice globally (Open Government Partnership, 2016). Originally convened by Brazil, Indonesia, Mexico, Norway, the Philippines, South Africa, the United Kingdom and the United States, it now consists of 65 members, including Argentina and Chile, and requires member countries to develop and implement commitments to achieving openness of government information. Whilst the ultimate aim for the OGP is to achieve transparency and accountability in its member countries, a 'sub' goal is for governments to work towards opening up data and information for civic and private innovation (OGP, 2015), thus providing the oxygen civic technologists require in order to operate. Latin America's emerging civic technology community is now maturing and becoming involved in the policy and campaigning aspects of digital democracy including OGP: This paper examines how Argentinian, Chilean and Mexican governments are responding to the rise of civic technology and the increasing demand for data and information against the backdrop of their official commitments to information rights and open government principles. Using a qualitative case study approach, it demonstrates how the bureaucracies involved in information disclosure have responded to civic technology implementations and their public usage, and highlights the institutional barriers to increasing meaningful openness in the countries studied. 


\section{Transparency, Accountability and the Role of Civic Technology}

Civic technology is a term largely used by the practitioner community, and rarely used within the academic literature. Often digital platforms and technologies within the literature are grouped under the umbrella of 'e-government' or 'ICTs' (Edwards, Brock and McGee, 2016; McCall and Dunn, 2012; Sandoval-Almazan and Gil-Garcia, 2012; Sommer and Cullen, 2009). These studies fail to make the distinction between top-down participatory technologies designed and implemented by institutions, and those that are developed outside of government by NGOs and community organisations. This is, however, an important distinction. Participatory systems that are designed by governments can be vulnerable to institutional biases and rationale, and the resulting tools may be built with inherent assumptions concerning the users needs (Bertot, Jaeger and McClure, 2008). Civic technologies emerge from outside the governmental sector. These technologies are not necessarily designed with the aim of being disruptive, but are designed by, and for, average citizens, using existing open data in innovative ways that can complement, overlay or frustrate the existing channels of information and communication previously controlled by institutions alone (Badger, 2012; Suri, 2013). This places civic technologies in a unique position at the interface of civic participation and governance, where innovations outside of the control of government may have significant impact in the channels of communication with citizens.

There is a general paucity of academic study relating to civic technologies as a distinct sphere of e-governance, and their impacts upon the environments in which they operate. Whilst several studies have used civic technology platforms to examine specific social behaviours online and offline (Boulianne, 2009; Gibson and Cantijoch, 2011), and others have investigated demographic usage of such tools (Rumbul, 2015; Sjoberg et al, 2015), the link between civic technology and the institutional change in government it may potentially cause has not been the subject of examination. Nevertheless, studies have argued for the importance of the role of ICTs in the 'information age' in facilitating openness, transparency and accountability in government administration (Bertot et al, 2010; Grimmelikhuijsen, 2012; Meijer, 2009 and 2012; Wong and Welch, 2004). Considerations of 'transparency" and 'accountability' have been significantly better represented within the existing literature. The relationship between accessible information and the ability of the citizenry and judiciary to hold government to account for the actions detailed in that information has been discussed by several authors (Gaventa and McGee, 2013; Janssen, 2012; Schedler, 1999; Worthy, 2010). Ultimately, transparency is considered ineffective without due accountability measures, and accountability has been described as requiring both answerability and enforcement to ensure its efficacy (Schedler, 1999). Another dimension to this evolution from transparency to accountability is the usability of information. Fox (2007) has pointed to the fundamental usability of disclosed information as key to meaningful transparency, arguing that information disclosed can be opaque, and therefore lacking in real transparency. This is particularly pertinent when considering the use of civic technology and ICTs in drawing data from government sources and publishing necessarily coherent information. ICTs and civic technologies have the capacity to process and present complex data in a user-friendly format, and this is a significant tool in moving from mere disclosure of information, towards genuine transparency, accountability and universal usability of useful data. However, civic technologies are a means to 
an end, rather than an end in itself, as ICTs in no way guarantee better governance (Breuer and Welp, 2014).

In comparison to individual information disclosure through traditional paper-based means, the ease of acquisition, storage, process, analysis and distribution of data means that transparency is considered an innate quality of civic technology (Grimmelikhuijsen, 2012; Meijer, 2009 and 2012). ICTs are able to automate data processing to reform oblique or opaque data sets, are able to scrape relevant information from thousands of lines of text, and produce coherent statistics, visualisations and searchable databases. The product of successful civic technology is therefore able to reduce the distance between government and citizen through greater citizen access to information and to decision makers, through providing real-time feedback, opportunities between citizen and government, and through enabling multiple opportunities for analysis and dissemination (Bertot et al, 2010; Wittemyer et al, 2014). There are, however, significant potential limitations to the development and implementation of civic technology, ranging from the acquisition of sufficient quality and quantity of data, the social-political institutional environment that ICTs exist within, the capacity of civic technology civil society groups, and the penetration and usage of the tools themselves. The digital divide persists in the majority of countries, including in Lain America, where internet access and skills deficits prevent more widespread ICT usage (Lopez, GonzalezBerrera and Patten, 2013). The quality and quantity of data available to ICTs and civic technologists is also a significant barrier in implementing effective digital tools (Longley and Bailur, 2014). Regarding RTI and open data reliant civic technologies, a fundamental commitment to, and practise of, openness and disclosure within government is essential to the successful operation of any given digital platform. This commitment and practise must go beyond mere disclosure in order to be considered 'effective', as the potentially opaque nature of documentation and data can render disclosure in itself pointless (Fox, 2007). Ineffective disclosure can also take the form of information overload in situations where unmanageably high volumes of poor quality data are provided (O'Neill, 2002). Such voluminous disclosures can render the information unusable and prevent the requestor from identifying the relevant information. Lack of provision of high quality data, such as data in machine readable format (rather than, for example, .PDF format), overload of poor quality or irrelevant data, or complete lack of disclosure by governments, all serve to frustrate the development and implementation of civic technology tools.

\section{ICTs and Governance in Latin America}

The potential social, political and administrative benefits of what has come to be known as civic technology was quickly recognised by scholars in the early 1990s (Breuer and Welp, 2014), however, concern for an emerging digital divide between developed nations and the Global South was highlighted as early as 1999 (OECD, 1999). Rhodes (2012), using World Bank data from 2010 demonstrated that 41 percent of a country's internet penetration could be linked to its level of democracy. However, within Latin America, internet penetration is lower than would be expected based upon the democracy index score of each country (Rhodes, 2012; Breuer and Welp, 2014). This has been linked to the paucity of competition in Latin American telecommunications markets (Barry, 2014), however high internet penetration is an essential factor in increasing the use of ICTs 
by citizens for civic activities. Without a critical mass of users, institutions are able to ignore attempts to change service delivery and communication through external ICTs. Boulianne (2009) has demonstrated a positive, if not overwhelming, impact of ICT usage upon civic engagement, and case studies conducted in less democratic contexts have demonstrated a clear positive link between internet usage and support for greater democracy (Tang et al, 2012). Whilst democracy is maturing across Latin America, issues of corruption, inequality, and a lack of transparency and accountability persist across states, and a belief that governments serve privileged minorities, rather than the public, remains entrenched (Breuer and Welp, 2014; Groshek and Bachmann, 2014). Nevertheless, government-led ICTs are widely used across Latin America (Breuer and Welp, 2014) for administrative efficiency purposes, and of the countries in the region, 15 have signed up to the Open Government Partnership, a global initiative promoting better governance through open government practices with a significant focus on ICTs and open data.

The question of how internet-enabled technologies affect government transparency and efficiency is a complex one, however it has been recognised that the benefits of such ICTs are vulnerable to the behaviour and attitudes of administrations (Longley and Bailur, 2014), particularly in less developed or less democratic countries, that seek to purposefully limit or control the information that is allowed to enter the public domain (Best and Wade, 2009; Groshek, 2009). The democratising effects of civic technologies are, therefore, severely limited among countries with less-developed democracies (Groshek, 2009). The findings of these studies have been questioned by scholars pointing to their use of data sets developed before modern social media and civic technologies developed widespread usage (Breuer and Welp, 2014), however it has not currently been demonstrated anywhere in the literature that such platforms have achieved more positive outcomes in regard to territories with a less developed democracy.

Whilst government-led ICT platforms are widespread within administrations in their usage across Latin America (Breuer and Welp, 2014), there continues to be a paucity of information on government and parliamentary activity in the public domain (Welp, 2011), and a much lower instance of government digital platforms providing the opportunity for genuine citizengovernment interaction or consultation (Araya and Barria, 2009). Whilst there have been several legislative moves by Latin American governments in recent years towards developing regimes within which freedom of information is enshrined as a right, at present the internal operations of institutions within many these countries remains for the most part closed to public scrutiny. There is also a lower penetration of civic technologies linking internal processes and information with external interest groups and citizens. There are, however, positive correlations between internet penetration and good governance emerging from Latin America, as detected in Mexico (Barry, 2014), where the government has undertaken radical reforms of its e-governance agenda and implemented significant regulatory measures to facilitate the disclosure of official information.

It is the very interface between civic technology and bureaucracy that this study seeks to examine. Whilst the governments of Argentina, Chile land Mexico may have made public commitments to increasing transparency as part of their entry to the OGP partnership, institutionalised and bureaucratic practice often takes longer to transition to new norms. A key feature of an institutionalised system is resistance to change (Hinich and Munger, 1993). North 
(1981) proposed that the evolution of institutions alongside organisational arrangements would 'lock-in' actors benefitting from the institutionalised system. This 'lock-in' manifests as a strong resistance to change by those actors within the organisation, and emerges from the incentive structure provided by the institution. In the case of access to information, knowledge is power (Pettigrew, 1972; Doctor, 1991), and control of it reinforces existing power structures. Change driven by an external attitudinal shift towards greater transparency therefore places individuals in existing positions of power in a new state of vulnerability. Institutionalised social reality is valid independently of an individual's own views (Meyer and Rowan, 1977), and this shared social reality is taken for granted as defining 'how we do things around here', hence perpetuating the embedded actions and responses of government officials. This is an echo of Hughes's (1939, pp283) assertion that it is unavoidable for human beings to get 'stuck in their ways' and that perpetuation of these habits often outlives the understanding of their meaning. Often, value is assigned to these processes, which exceeds the cost-benefit balance (Selznick, 1996), however, organisations conform to a set of institutionalised beliefs not only because they constitute the shared reality but also because there is an advantage to doing so (Meyer and Rowan, 1977; Scott, 1987), such as legitimacy, stability or consolidation of power.

Institutionalised behaviours within Latin American governments have been shown to hamper positive change and preserve existing powers structures (Mainwaring and Scully, 1995; Acemoglu and Robinson, 2006), therefore the implementation of open government principles and integration of civic technologies is potentially vulnerable to entrenched norms and values. Michener (2011) and Berliner (2015) have both noted the comparative inadequacy of Argentina's presidential decree which facilitates citizen's access to official information, when examined alongside Mexico's RTI legislation. However, the implementation of these legal instruments is significant. The most beautifully articulated and structured legislation may be vulnerable to misinterpretation or obstruction by the very public institutions that are legally bound to abide by it. Therefore, regardless of the legislative structure in which civic technology sits, it remains itself subject to the actions of state institutions in the provision of adequate data and information. The very process of requesting data or seeking information does, however, create its own impacts. Even without disclosure of information, institutions will be affected by any discernible increase or change in the volume or nature of requests for data and information. Changes in these factors such as increases in requests or requests for machine-readable data may themselves, be likely to catalyse an institutional response in order to meet the new nature and volume of requests. The potential for civic technologies to exhibit a discernible impact upon government behaviours in Latin America is therefore theoretically high, given that civic technologies both require official information to run, and in turn, create platforms that enable ordinary citizens to request information and data easily. This impact could be positive, in achieving greater volumes of good quality disclosures, however it could also manifest as a negative impact, in causing institutional behaviours to shift for the purpose of preserving existing levels of secrecy. 


\section{Research Methods}

The research consisted of three case studies focusing on the impact of civic technologies upon institutional behaviour in Latin America, specifically examining Argentina, Chile and Mexico. These countries were selected for comparison for their common language, their relative affluence and internet penetration within Latin America, and the diversity and developed state of their indigenous civic technology communities. The states are also members of the Open Government Partnership, having made commitments to openness as well as implementing legal channels through which citizens are able to request access to official information. In the cases of Chile and Mexico, this was through formal Freedom of Information legislation, whereas, in Argentina, this legal channel consisted of a Presidential decree.

A total of 47 semi-structured interviews were conducted with relevant government officials, politicians, and civic technologists. The participants were identified through a thorough review of the civic and government sphere in each territory, and this review was conducted in partnership with several indigenous groups to ensure a balanced and inclusive sample. Further snowball sampling was conducted during the interview phase to ensure the relevant individuals were included in the sample. A minor limitation in constructing the sample was experienced in Argentina with regard to accessing certain government officials, however five interviews with relevant government officials were conducted and this was considered sufficient to ensure a valid sample and thorough overview of the governance and execution of information disclosure at the federal level within Argentina.

Semi-structured interviews were formulated for individuals according to their affiliation, which was broken down into three main categories: official, politician or non-governmental stakeholder. The questions posed focused on official and unofficial working practices concerning the disclosure of information, professional governmental and non-governmental networks of individuals interested in information rights and open data, collaboration between non-governmental organisations and institutions, official and unofficial channels through which information could be acquired and communications conducted, legal and bureaucratic structures that governed the disclosure of data and information, the official hierarchy governing information flows including political interests, the development and implementation of international and national information policies, procedures for disclosure and broader media and community communications. Interviews were allowed to flow with the direction of conversation, with certain subjects being revisited later in the interviews to avoid restricting the points that participants were wishing to illustrate. Participants were given the option of conducting the interviews in either English or in Spanish with translation, and of the 47 interviews, 43 were conducted in English. Whilst caution must be exercised in quoting individuals using a second language, all participants communicating through the medium of English confirmed full fluency and confidence to participate in English prior to the interviews. Interviews were recorded and transcribed, and coded for specific themes and points of interest.

In addition to interviews, a number of official government reports and strategies were reviewed, and literature produced by civic technology organisations such as reports and accounts was used to provide background and context. These materials assisted in developing the interview 
questions and talking points, as well as validating anecdotal evidence gathered during the interview stages.

\section{Findings}

The three cases examined demonstrated a significant variance in the manner in which civic technology is impacting upon government behaviour. However, each territory demonstrated clear impacts as a direct result of civic technology itself. Argentina, Chile and Mexico are all members of the Open Government Partnership, and as a consequence of that membership have each made a comprehensive list of commitments to develop their official approach to opening up government information and improving engagement with citizens and civil society. In spite of these commitments, the day to day operation of government bureaucracy in each territory betrays a significant departure from generally accepted open government practices (Bauhr and Grimes, 2014). Whilst official rhetoric on open data and open government practices was commonly regurgitated by participants within each case, the manifestation of the underlying reluctance to release government information that existed within each of these bureaucratic regimes placed limitations on the real-world implementation of those OGP commitments through civic technologies. Within each case study, civil society civic technologists demonstrated historic and ongoing interactions with governments in requesting and using official information and data. The governmental reactions to these requests exhibit clear shifts in behaviour that enable the enduring limitation of the disclosure of requested information and prevent unknowable uses of official data. The findings of this study are segmented into two distinct analyses. Firstly, country-specific findings are examined, which explore the details and nuances of bureaucracy, institutional behaviour and information disclosed within each country studied. Secondly, thematic commonalities to emerge from the data are examined, which explore soft power, the digital divide and common institutional barriers to executing open governance principles.

\subsection{Country-Specific Findings}

The three countries studied exhibited clear legal and structural differences in their approach to information and data disclosure. The following sub-sections provide country-specific detail and context to each case study which demonstrates the institutional and bureaucratic factors at play in the disclosure of data and information.

\subsubsection{Argentina}

While it is evidenced that Argentina holds a high score on internet penetration and economic stability rankings in Latin America (International Telecommunications Union, 2012; World Bank, 2010), it scores low (rated only 66 and close to the bottom 10 rated countries) on the Global Right to Information Rating (RTI, 2015) and has arguably the least robust legislation of the three cases studied here in governing RTI, having only a Presidential decree limited to executive bodies and organisations receiving government money as opposed to a formal piece of legislation governing RTI. This study found that institutionalised attitudes to information disclosure existed within the 
Argentinian federal bureaucracy. The prevention or avoidance of information disclosure was valued and considered to be institutionally correct behaviour by individual workers within these federal governmental bodies. These attitudes severely limited the openness of the Argentinian federal government, and has resulted in access to information deteriorating in the last 7-10 years as a direct result of the publication of previously disclosed information used to challenge governmental behaviours within the media. The online tools developed by civic technology groups using government information, in several cases, generated unflattering press coverage for the government, and as such, information and data provision materially contracted. This contraction has taken the form of a decline in the quality of responses to requests for information. Federal government employees in Argentina reported being more reluctant to disclose information in line with the Presidential decree than in previous years because of the higher risk of that information being used at scale and in a manner that could portray the government in a negative fashion. This narrative was confirmed by civil society groups that had used government information in their ICTs, with several noting that whereas in 2008 or 2009 information had been provided to them in .XML or .CSV format, in later years the same information was either not disclosed, disclosed in paper form, or disclosed in a format that was incompatible with direct annual comparison.

Provision of official information has now, according to the participants of this study, predominantly moved to an in-person paper-based activity, meaning that individuals have to physically attend an official office to make a request for documentation or data, and must repeatedly return to check the status of their request. If the request is fulfilled, the information provided is predominantly in paper format. Very little information is now disclosed electronically at the federal level. The official explanation for this was due to the potential for tampering in regard to electronic or machine-readable data, however public sector participants noted that a culture of secrecy persists within the federal government, and that the accepted approach to requests for information was to disclose as little as possible, if anything. This secrecy was not necessarily a screen to protect wrongdoing, but an institutionalised attitude to government information that did not consider government information 'to be anyone else's business', and sought to avoid negative press headlines. Interviews with officials and politicians in Argentina reinforced these claims. Several officials discussed the potential personal risks of complying with legislation to be demotion or even loss of employment, even in situations where the provision of information electronically would have been perfectly legal. Similarly, a lack of understanding of the civic technology NGO sector and its goals caused officials and politicians to mistrust the motives of organisations in requesting information. Whilst no cover-up of wrong-doing was evident, a culture of government scrutiny is discouraged. The latitude for dissent provided to NGO groups in Argentina is minimal, with NGO groups not necessarily considered to be 'critical friends' to government, as part of a relationship in which the NGO sector seeks to provide constructive criticism and policy advice to enable the government to improve policy (Brinkerhoff, 2002; Rumbul, 2015). Rather, NGOs are seen more as direct challengers to government authority funded by international powers attempting to destabilize the country. Political anti-USA rhetoric in Argentina was strong at the time of the research due to renewed political discussion concerning Argentina's debt burden, and as such, officials and politicians interviewed for this study commonly viewed digital NGOs funded by international donors (including donors from the USA) 
with deep suspicion. The result, as demonstrated, has been a decline in the quality and quantity of information disclosed through official government channels using official legislation.

\subsubsection{Chile}

The varied impacts of civic technologies upon government behaviours in Chile has resulted in more subtle shifts towards information retention than is evident in Argentina. The Chilean government and official institutions demonstrate a clear external and top-down commitment to information disclosure and the use of open data, and the implementation and regulation of RTI laws has been considered moderately successful (Bertot et al, 2010). The installation of an RTI law commissioner external to the government departmental structure has lent public confidence to the operation of the law and the commissione's office has proven itself able to challenge government in decisions concerning information disclosure. However, RTI in Chile continues to suffer from the bureaucratic institutional environment it exists within. Civil servants faced with RTI requests 'err on the side of caution' as one participant stated, in making disclosures, meaning that the default action for any public servant processing a request for information is to find an excuse not to release the information. As in Argentina, this is mainly for fear of potential punishment from a superior for releasing the information in error or if the information is used in negative media stories concerning the government. Whilst training in the Chilean RTI law has been given to many public sector staff, and the regulator has a good library of information on its website, the majority of public sector employees remain mostly ignorant of the law, and are seemingly reluctant to embrace the attitude shift that must come with moving from a secretive bureaucracy to a more open-facing one. Institutionalised values remain focused on preserving the image and integrity of official bodies, and this rationalises individual reluctance to release information. The practice of other open government principles has been less well implemented, and provision of open data has been severely patchy, in most part due to a lack of cross-governmental strategy in producing and promoting open data, and to a lesser extent, due to a lack of skilled public officials across government institutions that are qualified in working with such data.

The quality of government RTI, open data and open government approaches reduces significantly the further away from Santiago the government body in question is situated. A significant part of this Santiago bias is due to logical factors; It is the capital (and largest) city in Chile, accommodates a significant number of international offices (including the UN), and is home to the country's political and educated classes. Connectivity is high in Santiago, and the resident population is on average more affluent than that outside of the capital. As such, the Chilean civic technology community has begun to grow, albeit in a concentrated area. Organisations such as FCI (Fundacion Cuidadano Intelligente) have taken the initiative to use ICTs to engage ordinary citizens in politics and policies, and have been successful in becoming a 'critical friend' to government in the development and operation of open government principles. In response to the pressure from organisations such as FCI, the Chilean government has moved from a closed and unrepresentative method of policy making to introducing measures designed to consult more widely with the public. Public use of civic technologies to engage with government information and policy-making in Santiago, as well as targeted campaigning by civic technology NGOs themselves, was considered to be a direct cause of certain government departments consulting 
more widely in policy-making. However, this has not been universal across government departments, nor has it penetrated local or municipal government. It was noted by participants that potentially controversial or unpopular policies are known to be directed to bypass public consultation and go straight to implementation, thus blemishing the new consultation programmes with accusations of tokenism. This again demonstrates that normalised bureaucratic practices are throttling the flow of information from government to the public sphere, particularly where the implementation of civic technologies is enabling citizens to become more engaged in policy.

\subsubsection{Mexico}

Amongst the three cases studied, the evidence of institutionalised resistance to information disclosure as a result of civic technology implementation is least evident in Mexico. The Mexican government has invested significantly in both RTI and in open government principles at the political, legislative and bureaucratic levels. Mexico's RTI law was updated in 2015 to rival and potentially exceed similar legislation in highly developed nations, and in addition to increasing the reach of the legislation to include a higher volume of agencies and organisations, it includes quality-related provisions on information disclosure, such as compelling data or information to be usable (i.e., provided in machine-readable formats). The regulator of RTI in Mexico is extremely well-funded in comparison to other publicly funded bodies, and commands public and governmental confidence in its independence from government. Complementing its internal drive for greater openness and transparency, Mexico has been active on the international stage in promoting its commitment to open governance, and operated as co-chair of the OGP in 2015 and hosted the international OGP summit in the same year. The Mexican President has also created a digital transformation office within the Presidential office structure, and has installed open government champions within each government department, responsible for overseeing the departmental implementation of open government principles and for monitoring and reporting progress. This is the clearest and most overt strategic top-down commitment to open government and access to information of the three cases studied. The core staffing of the digital transformation office were widely recruited from large NGOs in Mexico City and beyond, with individuals that are well-educated and independent (without familial ties) of the political regime. This demonstrates a clear commitment to avoiding Fox's (2007) 'opaque' or toothless transparency.

The civic technology community in Mexico is growing and thriving, and is being funded and encouraged by government, as well as by international donors, to develop as an entrepreneurial community. Mexico City in particular is a hub of digital activity, and the plurality and diversity of the civic tech community evidences the necessary conditions for a healthy section of civil society (Putnam, 1995; Fine and Harrington, 2003). In spite of this, information unfavourable to the regime continues to be suppressed, and in particular, information on individual politicians (such as expenses and use of public funds) is difficult to acquire legitimately. Journalists rarely use the RTI legislation for such requests, relying on inside sources and whistle-blowers to provide potentially controversial official information, and while civic technologists have been able to acquire a wide range of data on structural concerns such as transport and waste, they have experienced difficulty in gathering usable data for ICTs relating to finances, politics or politicians. Public sector workers 
here again admit to a fear of disclosing the wrong information and potentially being fired or having their career side-lined as punishment. Again, in Mexico, as in Argentina and Chile, it is clear that institutionalised bureaucratic norms are structured to retain control of information and how it is presented, and in doing so suppress the ability of civic technologies to fully flourish. Participants here, as in Chile and Argentina, describe numerous instances of information or data being disclosed to civic technologists, and its use by them resulting in negative public opinion or official embarrassment, being a factor in the limitation of data or information now disclosed. The institutionalised compulsion to withhold data to avoid such a scenario continues to be more powerful than top-down encouragement towards greater openness. Default attitudes to disclosure and fears of information being used by civic technologists to portray the government in a negative light restrict the flow of legitimately requested information.

\subsection{Key Themes}

The three case studies, as expected, exhibit significant variations due to their very different histories, economies, cultures and development. Civic technology has had a perceptible impact upon government action and bureaucratic thinking within each nation, and whilst these impacts have manifested in a number of ways, there are three key areas in which civic technology has shaped government behaviours in these case studies; in international relations, in a growing digital divide, and in bureaucratic practice.

\subsubsection{The Global Stage}

The OGP uses soft power to effect change (Nye, 2004; Slaughter, 2012). Although entry to the partnership requires minimal effort and commitments can be vague and amount to little change in the short term, governmental participants from each country studied cited membership of the OGP as akin to a form of 'quality mark'. The governments of Argentina, Chile and Mexico joined this global partnership to consolidate their external image in the world as developed, progressive and modern territories open for business, legally sound, and supportive of innovation. Admission also provides a platform for civil society to challenge these governments at an internal and international level. Civic technology groups have enjoyed a privileged amount of influence over government since the advent of the OGP and the submission of each country's plan. The commitments made to the OGP provide civic technologists, as well as other interested sections of civil society such as development NGOs, journalists and academics, with a roadmap for change and a ruler with which to measure government progress. The civil society fringe community of the OGP and the opportunities for civil society involvement in events and proceedings place pressure on governments to, at the very least, appear to be honouring and working towards achieving their commitments. At the institutional level this has manifested as shifting a reluctance towards information and data disclosure towards informal individual decisions that are not able to be measured or collated. Governments within OGP are unable to act brazenly in deciding whether to comply with their own legislation or commitments, and again, must provide a minimum level of service and disclosure to avoid civil society unrest that could embarrass the country on the world stage. This has prompted governments and officials to become increasingly more careful about their disclosures, but the evidence collected as part of this study demonstrates significant 
institutional barriers to effective achievement in this area. Whilst international relations has played a significant part in encouraging a top-down approach to open government commitments, it has not instigated the wholesale institutional and bureaucratic change necessary to implement open government effectively, and has been reluctant to do so directly because of the public relations frustrations borne of previous disclosures of information, in many cases, to civic technologists.

\subsubsection{Services in the Growing Digital Divide}

The institutional response to increases in connectivity and digital innovation is, in each case study, significantly different between national government and local or municipal government. It is not, however, the same in each case study. Whereas the central governments of Chile and Mexico demonstrate clear top-down commitments to, and implementation of, RTI and open government principles, in Argentina, it is the local and municipal levels of government, in particular in Buenos Aires, that are communicating with the civic technology community and supporting entrepreneurship and innovation in ICTs. In this isolated example, municipal governmental behaviour has actually shifted to embrace civic technology as a problem-solving solution in the delivery of public services. What is common in each case however, is the divergence between provision for those citizens who are digitally engaged, and those who do not have the physical access or skillset to engage with services in this way. Low levels of competition in the telecommunications market in Latin America, plus variations in coverage, mean that many citizens cannot afford or cannot access digital services or ICTs. Those who do have access tend to be the affluent, political and well-educated classes that are the most digitally engaged both within government and in civil society, and it is this small homogenous community that dominates the civic technology and open government conversation. At the macro-institutional level therefore, the impacts of civic technologies have been minimal in fundamentally changing government behaviours or priorities in servicing the least affluent communities. The wide variations in how layers and departments of government are approaching civic engagement via ICTs, with departments mostly operating in isolation, indicate that a digital divide could continue to grow without sufficient strategic intervention, and that the intended democratising effect of civic technology will inadvertently end up working only for those pre-existing socially and politically efficacious groups.

\subsubsection{An Institutionalised Fear of Bureaucratic Consequence}

The most common and clear effect of civic technology upon government behaviour has been to inhibit the confident disclosure of government information and data. Whereas 10 years previously, it was found that government officials would have likely provided information in paper copy without too much concern, the rise of RTI civic technologies and other civic ICTs has increased the levels of anxiety officials now experience in deciding whether or not to provide information, and this has resulted in fewer and poorer quality disclosures. Whilst it cannot be proven that there is malicious intent to deliberately withhold information within any of the countries studied, there is a common detectable reluctance by operational staff to release in particular, information in electronic formats and machine readable formats. Official excuses made by public sector employees for not disclosing information range from the risk of tampering to a lack of the 
information requested being held, but within each case participants admitted that reluctance to provide data or information was primarily due to the fear of what civic technologists might do with the information. Civic technologists have in each of the case study countries, used data or information to build ICTs for the public, ranging from searchable health information, to social and economic data, to refuse collection efficiency tools, to parliamentary monitoring websites. These tools have variously received public or media attention, and in some cases, inevitably the governments have been challenged on the content of the data. These negative experiences prompt many officials to ask new requestors why information is being requested. However, legally requests are 'usage blind', meaning that the intentions behind the request must not be a factor in whether information is disclosed, and it should in legal principle not be of consequence who is asking or why. Public officials are therefore anxious about whether the information that they provide will be used at scale and ultimately embarrass or cause trouble for the government, and fear that they will be subject to punitive measures if their disclosure results in such activity. Whilst few incidences of such measures were observed by participants, the common attitude within each of the bureaucracies was for individual civil servants to avoid making decisions that could harm their careers. One participant ${ }^{1}$ noted that it was "simply safer to find a way not to give out that data. Just in case".

This behaviour exhibits one of the issues facing bureaucracies moving from traditional information management to e-government and digital practices, especially in countries with a legacy of very closed and hierarchical power structures, and demonstrates the political difficulties in implementing civic technology; whilst the law and the technology can theoretically facilitate information disclosure and open up government information, the results of that disclosure may have the opposite effect in prompting governments to be more careful in their disclosures. Legislation can be very explicit in allowing certain information to be released, however this does not necessarily protect officials from the displeasure of politicians or senior officials that have to address any political controversy caused as a result of the disclosure. Wishing to retain their careers, many officials do not even consult with more senior managers concerning disclosure, they proceed with finding a reason not to disclose. This institutionalised behaviour requires a significant cultural shift within the public service, not only with regard to disclosure, but with regard to human resources practice, to enable officials to fully execute their obligations under the legislation in each of the case study countries without fear of recrimination.

\section{Conclusion}

The governments of Argentina, Chile and Mexico have each altered their behaviours in response to the rise of civic technologies, and these alterations exhibit clear institutionalised tendencies in seeking to preserve control over government information. Whilst each has committed publically to open government principles and been admitted to the OGP, each exhibits institutionalised barriers 
to the implementation of open government principles in practice. The impacts of civic technology have been shown to be responsible, at least in part, for the frustration of RTI and open data users, and is demonstrated in the limited quality and quantity of information disclosed to private individuals and civil society groups in these countries. The intended democratising and opening effects of civic technology have in fact caused a chilling effect in certain instances where officials acting in line with institutionalised norms and values are specifically inhibiting information provision and reducing openness. This is by no means a blanket or organisationally directed policy, rather, it is the result of institutionalised and rationalised bureaucratic and individual logics informed by historic and cultural working practices. This demonstrates a significant flaw in viewing civic technology and ICTs as solutions in themselves, rather than as tools to assist in achieving solutions, and this study contributes to the existing literature that examines the risks of open government and open data movements (Janssen, 2012) as well as the body of literature citing the continuing deficiencies of open government practices in Latin America (Mendoza, 2013). Institutionalised norms and values across governmental organisations must shift and penetrate through each layer of hierarchy if the functions of government transparency are to align with OGP commitments and general good practice in open governance. Currently, the top-down approaches taken by the three cases studied are not penetrating underlying organisational norms and values. This study has demonstrated clearly that civic technology has had a perceptible impact upon government behaviours in Argentina, Chile and Mexico. Aspects of the OGP membership negotiations, strategy development and the pressures of the civil society OGP community did not form part of the study, however government work in this area was intertwined with much of the conversation about civic technology and RTI. Further investigation of the effects of OGP and related civil society campaigning upon government behaviours in information and data disclosure would provide valuable context in understanding how governments are developing their information disclosure practices, and how civic technology is impacting upon the quality of data. At present, however, citizens, civic technologists and other NGOs continue to suffer from disruptive bureaucratic and institutionalised practices that undermine public commitments to open governance in Argentina, Chile and Mexico.

\section{References}

Acemoglu, D., and Robinson, J. A. (2006). De facto political power and institutional persistence. The American Economic Review, 96(2), 325-330. doi:10.2307/30034667

Alaveteli (2016) Getting Started. Retrieved from http://alaveteli.org/docs/getting_started/

Araya, M. E., and Barria, T. D. (2009). E-participation en el Senado Chileno; Aplicaciones Deliberativas? Convergencia, 51(6), 236-268.

Badger, E. (2012). The next big start-up wave: Civic technology. Retrieved from http:/ / www.citylab.com/tech/2012/06/next-big-start-wave-civic-technology/2265/

Bailur, S., and Longley, T. (2014). The impact of online Freedom of Information tools: What is the evidence? Retrieved from https://www.mysociety.org/files/2014/11/FOI-Impact_Part-2-Practitioner-Study06.pdf 
Bailur, S., Wittemyer, R., Anand, S., Park, K.-R., and Gibler, B.-S. (2014). New Routes to Governance: A Review of Cases in Participation, Transparency, and Accountability. In B.-S. Gigler and S. Bailur (Eds.), Closing the Feedback Loop (pp. 43-70). Washington D.C.: World Bank Publications.

Barnett, W. A., Hinich, M., and Schofield, N. (1993). Political economy: Institutions, competition and representation: Proceedings of the Seventh International Symposium in Economic Theory and Econometrics (Vol. 7). Cambridge University Press.

Barry, J. J. (2009). A digital sublime or divide?: the impact of information communication technology on the poor in Latin America. In A. Breuer and Y. Welp (Eds.), In Digital technologies for democratic governance in Latin America: opportunities and risks (pp. 33-55). Routledge.

Bauhr, M., and Grimes, M. (2013). Indignation or resignation: The implications of transparency for societal accountability. Governance, 27(2), 291-320. doi:10.1111/gove.12033

Bertot, J. C., Jaeger, P. T., \& McClure, C. R. (2008). Citizen-centered e-government services: benefits, costs, and research need: Proceedings of the 2008 international conference on Digital government research. (pp. 137-142). Digital Government Society of North America.

Bertot, J. C., Jaeger, P. T., and Grimes, J. M. (2010). Using ICTs to create a culture of transparency: Egovernment and social media as openness and anti-corruption tools for societies. Government Information Quarterly, 27, 264-271. doi:10.1016/j.giq.2010.03.001

Best, M. L., and Wade, K. W. (2009). The Internet and democracy: Global catalyst or democratic dud? Bulletin of Science, Technology and Society, 29(4), 255-271. doi:10.1177/0270467609336304

Boulianne, S. (2009). Does Internet use affect engagement? A Meta-Analysis of research. Political Communication, 26(2), 193-211. doi:10.1080/10584600902854363

Breuer, A., and Welp, Y. (Eds.). (2014). Digital technologies for democratic governance in Latin America. Routledge.

Brinkerhoff, J. M. (2002). Assessing and improving partnership relationships and outcomes: a proposed framework. Evaluation and program planning, 25(3), 215-231.

Calland, R., and Bentley, K. (2013). The impact and effectiveness of transparency and accountability initiatives: Freedom of information. Development Policy Review, 31, s69-s87. doi:10.1111/dpr.12020

Costa, S. (2013). Do freedom of information laws decrease corruption? Journal of Law, Economics, and Organization, 29(6), 1317-1343. doi:10.1093/jleo/ews016

Dagnino, E. (2011). Civil Society in Latin America. In The Oxford handbook of civil society (pp. 122-133). United States: Oxford University Press Inc.

Doctor, R. D. (1991). Information technologies and social equity: Confronting the revolution. Journal of the American Society for Information Science, 42(3), 216-228. doi:10.1002/(sici)1097-4571(199104)42:3<216::aidasi7>3.0.co;2-y

Edwards, D., Brock, K., \& McGee, R. (2016, February). Transforming governance: What role for technologies? Retrieved August 23, 2016, from IDS, http://mobile.opendocs.ids.ac.uk/opendocs/handle/123456789/11675 
Fine, G. A., and Harrington, B. (2004). Tiny Publics: Small groups and civil society. Sociological Theory, 22(3), 341-356. doi:10.1111/j.0735-2751.2004.00223.x

Fox, J. (2007). The uncertain relationship between transparency and accountability. Development in Practice, 17(4-5), 663-671. doi:10.1080/09614520701469955

Gaventa, J., \& McGee, R. (2013). The impact of transparency and accountability initiatives. Development Policy Review, 31, s3-s28. doi:10.1111/dpr.12017

Gibson, R., and Cantijoch, M. (2013). Conceptualizing and measuring participation in the age of the Internet: Is online political engagement really different to Offline? The Journal of Politics, 75(03), 701-716. doi:10.1017/s0022381613000431

Gigler, B.-S., and Bailur, S. (Eds.). (2014). Closing the feedback loop: Can technology bridge the accountability gap? New York, NY, United States: World Bank Publications.

Global Right To Information Rating. (2015). Global Right To Information Rating Country data. Retrieved August 17, 2016, from http://www.rti-rating.org/country-data

Grimmelikhuijsen, S. (2012). A good man but a bad wizard. About the limits and future of transparency of democratic governments. Information Polity, 17(3,4), 293-302. doi:10.3233/IP-2012-000288

Groshek, J. (2009). The democratic effects of the Internet, 1994-2003. International Communication Gazette, 71(3), 115-136. doi:10.1177/1748048508100909

Groshek, J., and Bachmann, I. (2014). ). A Latin Spring?: examining digital diffusion and youth bulges in modeling political change in Latin America. In A. Breuer and Y. Welp (Eds.), Digital technologies for democratic governance in Latin America: opportunities and risks (pp. 17-32). Routledge.

Hinich, M., and Mungler, M. (1993). Political Ideology, Communication and Community. In W. Barnett and M. Hinich (Eds.), Political Economy: Institutions, Competition, and Representation : Proceedings of the Seventh International Symposium in Economic Theory and Econometrics. Cambridge: Cambridge University Press.

Hughes, E. (1937). Institutional Office and the Person. American Journal of Sociology, 43(3), 404-413. doi:10.1086/217711

Janssen, K. (2012). Open government data: Right to information 2.0 or its rollback version? Retrieved August 17, 2016, from SSRN, http:/ / papers.ssrn.com/sol3/papers.cfm?abstract_id=2152566

Khurram, H. (2015). Increasing the impact of Civic Tech Platforms. Retrieved from http://https://www.omidyar.com/blog/increasing-impact-civic-tech-platforms

Knight Foundation. (2015). Assessing Civic Tech Impact: Case Studies and Resources for Tracking Outcomes. Retrieved from

http://www.knightfoundation.org/media/uploads/publication_pdfs/NI_Knight_CivicTechAssessme nt_Mar2015.pdf

Lopez, M. H., Gonzalez-Barrera, A., \& Patten, E. (2013). Closing the digital divide: Latinos and technology adoption. Washington, DC: Pew Hispanic Center.

Mainwaring, S., and Scully, T. (Eds.). (1996). Building democratic institutions: Party systems in Latin America. Stanford: Stanford University Press. 
McCall, M. K., \& Dunn, C. E. (2012). Geo-information tools for participatory spatial planning: Fulfilling the criteria for "good" governance? Geoforum, 43(1), 81-94. doi:10.1016/j.geoforum.2011.07.007

Meijer, A. J. (2009). Understanding modern transparency. International Review of Administrative Sciences, 75(2), 255-269. doi:10.1177/0020852309104175

Meijer, A. J. (2012). Introduction to the special issue on government transparency. International Review of Administrative Sciences, 78(1), 3-9. doi:10.1177/0020852311435639

Mendoza, G. Q. (2013). Open government in Latin America limited to transparency, and access to information. In Proceedings of the 14th Annual International Conference on Digital Government Research (pp. 269-270). ACM. doi:10.1145/2479724.2479767

Meyer, J., and Rowan, B. (1977). Institutionalized Organizations: Formal Structure as Myth and Ceremony. American Journal of Sociology, 83(2), 340-363. doi:10.1086/226550

Moon, M. J., \& Welch, E. W. (2005). Same bed, different dreams? A comparative analysis of citizen and bureaucrat perspectives on e-government. Review of Public Personnel Administration, 25(3), 243-264.

MuckRock (2016) About MuckRock. Retrieved from https://www.muckrock.com/about/

North, D. C. (1981). Structure and Change in Economic History. Politics and Society, 11(4), 511-512. doi:10.1177/003232928201100416

Nye, J. S. (2004). Soft power: The means to success in world politics. PublicAffairs

OECD (1999) OECD Communications Outlook. Retrieved August 17, 2016, from http:/ /www.oecdilibrary.org/science-and-technology/oecd-communications-outlook-1999_comms_outlook-1999-en

O'Neill, O. (2002). A question of trust: The BBC Reith lectures 2002. Cambridge University Press

Open Government Partnership (2016) About. Retrieved from http:/ /www.opengovpartnership.org/about

Open Government Partnership (2014) Open Government Partnership: Four Year Strategy 2015-2018. Retrieved from http://www.opengovpartnership.org/sites/default/files/attachments/4YearAP-Online.pdf

Patel, M., Sotsky, J., Gourly, S., and Houghton, D. (2013). The Emergence of Civic Tech: Investment in a growing field. Knight Foundation: Miami. Available at:

http://www.knightfoundation.org/media/uploads/publication_pdfs/knight-civic-tech.pdf

Putnam, R. D. (1995). Bowling alone: America's declining social capital. Journal of Democracy, 6(1), 65-78. doi:10.1353/jod.1995.0002

Rhodes, P. (2012) Nordic countries dominate the world in internet penetration, graphoftheweek.org, Available from http:/ / www.graphoftheweek.org/2012/03/nordic-countries-dominate-world-in.html

Rumbul, R. (2015). Critical friend or absent partner? Institutional and organisational barriers to the development of regional civil society. European Urban and Regional Studies, 0969776414564017.

Rumbul, R. (2015). Who Benefits From Civic Technology? Demographic and Public Attitudes Research into the Users of Civic Technology. mySociety. Retrieved from https://www.mysociety.org/files/2015/10/demographics-report.pdf 
Sandoval-Almazan, R., \& Gil-Garcia, R. J. (2012). Are government internet portals evolving towards more interaction, participation, and collaboration? Revisiting the rhetoric of e-government among municipalities. Government Information Quarterly, 29, S72-S81. doi:10.1016/j.giq.2011.09.004

Schedler, A. (1999). Conceptualizing Accountability. In L. Diamond and M. Plattner (Eds.), The Selfrestraining State: Power and Accountability in New Democracies (pp. 13-28). London: Lynne Rienner.

Scott, R. (1987). The Adolescence of Institutional Theory. Administrative Science Quarterly, 32(4), 493-511. doi: $10.2307 / 2392880$

Selznick, P. (1996). Institutionalism "Old" and "New." Administrative Science Quarterly, 41(2), 270-277. doi:10.2307/2393719

Sjoberg, F. M., Mellon, J., and Peixoto, T. (2015). The effect of government responsiveness on future political participation. SSRN. doi:10.2139

Slaughter, A.-M. (2012). Remarks, the big picture: Beyond hot spots and crises in our interconnected world. Penn state journal of law and international affairs

Sommer, L., \& Cullen, R. (2009). Participation 2.0: A case study of e-participation within the New Zealand Government. In System Sciences, 2009. HICSS'09. 42nd Hawaii International Conference on (pp. 1-10). IEEE.

Suri, M. V. (2013). From crowd-sourcing potholes to community policing: Applying Interoperability theory to analyze the expansion of "open311". SSRN. doi:10.2139

Tang, M., Jorba, L., \& Jensen, M. J. (2012). Digital media and political attitudes in China. Digital Media and Political Engagement Worldwide: A Comparative Study, 221-239.

Welp, Y. (2008). América Latina en la era del gobierno electrónico. Análisis de la introducción de nuevas tecnologías para la mejora de la democracia y el gobierno. Revista del CLAD Reforma y Democracia, 173192.

Welp, Y. (2013). Bridging the political gap? The adoption of ICTs for the improvement of Latin American parliamentary democracy. E-Parliament and ICT-Based Legislation: Concept, Experience and Lessons. doi:978146661852710.4018/978-1-4666-1852-7.ch087

Wittemyer, R., Bailur, S., Anand, N., Park, K.-R., Gigler, B.-S. (2014). New Routes to Governance: A Review of Cases in Participation, Transparency, and Accountability, in Closing the Feedback Loop, World Bank Publications: Washington D.C.

Wong, W., \& Welch, E. (2004). Does e-government promote accountability? A comparative analysis of website openness and government accountability. Governance, 17(2), 275-297.

Worthy, B. (2010). More open but not more trusted? The effect of the freedom of information act 2000 on the United Kingdom central government. Governance, 23(4), 561-582. doi:10.1111/j.1468-0491.2010.01498.x

Worthy, B. (2012). Book Review: Freedom of Information in Scotland in Practice, by Kevin Dunion. Information Polity, 17(2), 197-199.

Worthy, B., and Hazell, R. (2014). The impact of the freedom of information act in the UK. Retrieved August 19, 2016, from http:// papers.ssrn.com/sol3/papers.cfm?abstrac 


\section{About the Author}

\section{Rebecca Rumbul}

Rebecca Rumbul is Head of Research at mySociety, an international development NGO specialising in developing digital tools to empower citizens. Her PhD and subsequent research focused on Politics, Public Administration and Civil Society. She lectures part-time for Cardiff University, and is a Fellow of The Winston Churchill Memorial Trust and the Royal Society of Arts. 